\title{
EL TRÁFICO DE ÓRGANOS HUMANOS. ESTUDIO DE SU SANCIÓN EN LA LEGISLACIÓN CHILENA Y ESPAÑOLA
}

\author{
Trafficking in human organs. \\ Study about its sanction on the Chilean and Spanish legislation
}

Clara Moya Guillem*

\begin{abstract}
Resumen: El objeto de este trabajo consiste en un estudio comparado de las más recientes disposiciones sancionadoras del tráfico de órganos humanos incorporadas a la legislación de Chile y España. Para ello, se parte de la normativa que proclama el principio de gratuidad en materia de trasplantes, y se analizan las infracciones administrativas y penales previstas para sancionar, sobre todo, las conductas que se cometan en este ámbito con ánimo de lucro. Este estudio comparado permitirá conocer, por un lado, las principales notas comunes a ambos ordenamientos jurídicos, así como aquellas otras en las que divergen; y, por otro lado, los aspectos más problemáticos que plantea la aplicación de dichas normas sancionadoras. Tanto las discrepancias entre estas legislaciones como las dificultades que plantea su aplicación reflejan la complejidad para afrontar jurídicamente este problema de una forma satisfactoria.
\end{abstract}

Palabras clave: tráfico de órganos humanos - derecho comparado - conflicto de normas comercio de órganos humanos - trata de personas

\begin{abstract}
The objective of this paper consists of a compared study of the most recent penalty provisions about trafficking in human organs incorporated to the Chilean and Spanish legislations by assuming the regulations that proclaim the principle of free provision in the field of organ transplants, and analyzing administrative breaches and criminal offences provided in order to sanction above all the conducts committed in this area with the aim of getting economic benefit. This compared study will show, on the one hand, the main common aspects of both legal systems, as well as the divergent points; and, on the other hand, the most problematic aspects posed by the implementation of those penalty provisions. Not only the differences among those legislations but also the difficulties of their implementation reflect the complexity to satisfactorily deal with this problem from the legal point of view.
\end{abstract}

Keywords: trafficking in human organs - comparative law - conflict of laws - human organ trade - trafficking in human beings

\footnotetext{
* Investigadora en formación de la Universidad de Alicante. Licenciada en Derecho por la Universidad de Alicante; Licenciada en Criminología por la Universitat de València; y Máster en Sistema de Justicia Penal por la Universitat de Lleida. Correo electrónico: clara.mg@ua.es

Este trabajo se enmarca en el proyecto de investigación "Nuevos límites penales para la autonomía individual y la intimidad" (DER2011-26909/JURI) del Ministerio de Economía y Competitividad de España. La investigación se ha desarrollado gracias a una estancia de investigación en la Universidad Diego Portales de Santiago de Chile, financiada por la Beca Iberoamericana para Jóvenes Profesores e Investigadores (España 2013) del Banco de Santander (Santander Universidad).
}

Este artículo fue recibido el 31 de marzo de 2014, siendo aprobada su publicación el 3 de junio de 2014. 


\section{El problema de la escasez de órganos humanos disponibles para trasplantar}

El trasplante de órganos de origen humano constituye uno de los avances terapéuticos más relevantes del siglo XX. Gracias al desarrollo técnico que ha experimentado se ha convertido en una práctica rutinaria en los hospitales de todo el mundo. De hecho, actualmente se estima que se llevan a cabo aproximadamente 100.000 trasplantes de órganos cada año. ${ }^{1}$

Sin embargo, el éxito de la terapia del trasplante ha generado un notable incremento de la demanda y, por ello, el número de órganos disponibles para trasplantar ha devenido insuficiente. La dramática situación que esta carencia de órganos genera se observa en los siguientes datos: en Europa fallecen 9 personas cada día a la espera de un órgano y en EE.UU. mueren 18 enfermos cada día por el mismo motivo. ${ }^{2}$ Además, por lo que se refiere a la realidad chilena y española, de los 1.723 enfermos que pasaron por las listas de espera oficiales de Chile en el 2012, solo 400 consiguieron ser trasplantados; y de los 7.460 enfermos que pasaron por listas de espera de España en ese mismo año, solo 4.000 recibieron un órgano sano. ${ }^{3}$

Precisamente esta carencia de órganos disponibles para trasplantar es una de las principales causas por las que el tráfico de órganos humanos ha irrumpido en las sociedades actuales. ${ }^{4}$ Este fenómeno, según ha afirmado la ONU, constituye una flagrante violación de los derechos humanos, incluida la integridad de sus víctimas. ${ }^{5}$ Por ello, importantes instituciones como la Organización Mundial de la Salud (OMS, en adelante) o la Red/Consejo iberoamericano de donación y trasplantes, de las que tanto Chile como España forman parte, vienen exigiendo en los últimos años mayores esfuerzos para combatir este grave problema. ${ }^{6}$

\footnotetext{
${ }^{1}$ Dato del Observatorio Global sobre Donaciones y Trasplantes (2010).

${ }^{2}$ Datos ofrecidos del Consejo de Europa (2012) y el U.S. Department of Health and Human Services.

${ }^{3}$ Sobre ello, Consejo de Europa (2013).

${ }^{4}$ Un estudio conjunto realizado por la Organización de las Naciones Unidas (ONU, en adelante) y el Consejo de Europa, en el 2009, considera que entre 5\% y 10\% de los riñones trasplantados cada año en el mundo provienen del tráfico ilegal (Joint Study Trafficking in organs, tissues and cells and trafficking in human beings for the purpose of the removal organs). En este mismo estudio, junto a la escasez de órganos disponibles para trasplantar, se alude a las desigualdades económicas y a la falta de equidad en el acceso al trasplante como causas generadoras del fenómeno.

5 Resolución 59/156, sobre Prevención, lucha y sanciones contra el tráfico de órganos humanos, aprobada por la Asamblea General de la ONU en el 2004.

${ }^{6}$ Se trataría, en concreto, por lo que a la OMS se refiere, de las resoluciones 40.13, sobre los principios en materia de trasplante de órganos; 42.5, sobre prevención de la compra y venta de órganos humanos; 44.25, sobre el trasplante de órganos humanos; 57.18, sobre el trasplante de órganos y tejidos humanos; y 63.22, sobre el trasplante de órganos y tejidos humanos. Y, por lo que a la Red/Consejo iberoamericano de donación y trasplantes se refiere, en particular, serían destacables la Declaración de Mar del Plata de 2005; y la Recomendación (2008) 8, Consideraciones bioéticas sobre la donación y el trasplante de órganos, tejidos y células.
} 
Con motivo de los peligros inherentes al tráfico de órganos humanos, reiteradamente advertidos por las organizaciones internacionales, la mayoría de los Estados han optado por sancionarlo. Chile y España han sido dos de los Estados que lo han regulado recientemente tanto en el orden administrativo como en el penal. Y, precisamente, la normativa sancionadora del tráfico de órganos humanos en estos dos países constituye el objeto del presente trabajo.

Teniendo ello en cuenta, a continuación me referiré a la legislación chilena que prevé la necesaria gratuidad de la donación y el trasplante de órganos, exponiendo las sanciones administrativas previstas para el caso de ánimo de lucro por parte de quienes intervienen. Tras esta exposición de la normativa administrativa chilena, analizaré los tipos penales que castigan el tráfico de órganos humanos en este mismo país, exponiendo la única sentencia que, hasta el momento, ha condenado en aplicación de estas figuras penales. Seguidamente, llevaré a cabo un análisis de la legislación administrativa y penal sancionadora del tráfico de órganos humanos en relación con el ordenamiento jurídico español. En este ámbito, me detendré, sobre todo, en el estudio del bien jurídico protegido y de las conductas típicas previstas. Y, finalmente, explicaré, a modo de conclusiones, las notas comunes a ambas legislaciones, así como aquellas otras en las que divergen.

\section{La sanción del tráfico de órganos humanos en la legislación chilena y en la española}

La comunidad internacional, desde los años 70, viene reiterando en sus distintos instrumentos normativos que ni el cuerpo humano ni sus partes pueden ser objeto de transacción comercial. ${ }^{7}$ Esta máxima, en la que se inserta el principio de extracomercialidad de los órganos humanos, ha sido acogida por los ordenamientos jurídicos nacionales como uno de los pilares básicos sobre los que se sostienen los sistemas de donación y trasplante de órganos. Así, la prohibición de traficar con órganos humanos procedería, precisamente, de dicho principio, que en esta materia se ha consagrado como el principio de gratuidad.

\footnotetext{
${ }^{7}$ Entre otras, la Resolución 63.22 de la OMS de 2010, sobre el trasplante de órganos y tejidos humanos, que ha actualizado los "Principios Rectores sobre Trasplante de células, tejidos y órganos humanos" de 1991, determina, en su quinto principio, que las células, tejidos y órganos deberán ser objeto de donación a titulo exclusivamente gratuito, sin ningún pago monetario u otra recompensa de valor monetario. Deberá probibirse la compra, o la oferta de compra, de células, tejidos u órganos para fines de trasplante, así como su venta por personas vivas o por allegados de personas fallecidas. Asimismo, la Red/Consejo iberoamericano de donación y trasplantes también ha proclamado este principio, especialmente, en la Declaración de Mar del Plata de 2005 y en la Recomendación 2008 (8), Consideraciones bioéticas sobre la donación y el trasplante de órganos, tejidos y células. Este último instrumento normativo establece que [t] odos los países deben legislar la probibición absoluta de comerciar con órganos y tejidos, así como elaborar un código ético que oriente el desarrollo de los procesos de extracción y transplante. También es fundamental la existencia por parte del Estado de organismos reconocidos y sin fines de lucro que se encarguen de controlar la procedencia, destino y trazabilidad de todos los órganos y tejidos.
} 
Moya - El tráfico de órganos humanos. Estudio de su sanción en la legislación chilena y española

El tráfico de órganos humanos es un fenómeno que suele identificarse, aunque con matices, con el comercio de órganos humanos. ${ }^{8}$ Por ello, aunque la legislación que regula el trasplante de órganos declare otros principios a respetar en el proceso -así como las correspondientes sanciones para los casos de vulneración de los mismos-, en este trabajo solo haré referencia al principio de gratuidad. ${ }^{9}$ Resulta conveniente advertir, no obstante, que, en el ámbito jurídico-penal chileno y español, la sanción del tráfico de órganos humanos no se ha limitado al comercio de los mismos, que equivaldría a la vulneración del principio de gratuidad, sino que se ha ampliado, como se verá, a otro tipo de conductas que, aunque llevadas a cabo sin ánimo de lucro, resultan ilegales. ${ }^{10}$

${ }^{8}$ El "tráfico de órganos humanos" entendido en el sentido de comercio de órganos humanos ha
sido definido como una política o práctica en la que un órgano se trata como una mercancía, incluida la compra,
venta o utilización para conseguir beneficios materiales (definición que ofrece la Declaración de Estambul
sobre el tráfico de órganos y el turismo de trasplantes de 2008 , bajo la denominación de
"comercialización de trasplantes"). También en este sentido, por ejemplo, el Informe "Prevención,
lucha y sanciones contra el tráfico de órganos humanos" del $15^{\circ}$ periodo de sesiones de la
Comisión de Prevención del Delito y Justicia Penal del Consejo Social y Económico de la ONU de
2006 (E/CN.15/2006/10), que define el fenómeno como la transferencia de órganos extirpados
ilícitamente de una manera organiqada y con fines comerciales. Esta no es, sin embargo, una definición consensuada de "tráfico de órganos humanos". Así, al tratar de delimitar este fenómeno, algunos lo equiparan, como he expuesto, al comercio de órganos; pero, otros, añaden que también es "tráfico de órganos humanos" la ausencia de voluntariedad en la donación; y, algunos, incluso, al definir el fenómeno apuntan a otras ilegalidades cometidas en el proceso tendente al trasplante, aunque no haya ánimo de lucro ni ausencia de voluntariedad (así, por ejemplo, califican de "tráfico de órganos humanos" la alteración del orden de las listas de espera). Sin embargo, el debate sobre qué es el "tráfico de órganos humanos" no va a ser abordado en este trabajo porque ello excedería del objetivo propuesto.

${ }^{9}$ La Recomendación 2008 (8), Consideraciones bioéticas sobre la donación y el trasplante de órganos, tejidos y células, de la Red/Consejo Iberoamericano de donación y trasplantes, establece, en esta dirección, que la donación de órganos, tejidos y células para el trasplante debe ser gratuita, debiendo probibirse el pago o cobro de dinero por células, tejidos y órganos, así como cualquier transacción comercial en esta esfera.

En Chile, aunque no existe un precepto que declare el conjunto de principios orientadores en esta materia, estos se deducen de los artículos que se expondrán a continuación. Y en España, los principios básicos que rigen la obtención y utilización clínica de los órganos humanos serían los principios de voluntariedad, altruismo, confidencialidad, ausencia de ánimo de lucro y gratuidad, de forma que no sea posible obtener compensación económica ni de ningún otro tipo por la donación de ninguna parte del cuerpo bumano (artículo 4.2 del Real Decreto 1723/2012, de 28 de diciembre, por el que se regulan las actividades de obtención, utilización clínica y coordinación territorial de los órganos humanos destinados al trasplante y se establecen requisitos de calidad y seguridad).

10 Países como EE.UU., Reino Unido o Colombia sí se han limitado a sancionar penalmente las conductas tendentes a la obtención del órgano y su posterior trasplante cuando medie ánimo de lucro. 
REJ - Revista de Estudios de la Justicia - No 20 - Año 2014

\section{a) La legislación chilena sancionadora del tráfico de órganos humanos}

En Chile, la regulación del trasplante de órganos se ubica en la Ley $\mathrm{N}^{\circ} 19.451$ de 1996, de normas sobre trasplante y donación de órganos (en adelante, Ley $\mathrm{N}^{\mathrm{o}}$ 19.451).

Esta ley proclama el principio de gratuidad en su artículo 3:

La donación de órganos sólo podrá realizarse a título gratuito. Se probibe, será nulo y sin ningún valor el acto o contrato que, a titulo oneroso, contenga la promesa o entrega de un órgano para efectuar un trasplante. Los gastos en que se incurra con motivo de la extracción del órgano que se dona, forman parte de los gastos propios del trasplante y serán imputables al sistema de salud del receptor de acuerdo a las normas legales, reglamentarias y contractuales que correspondan.

Y el Decreto $\mathrm{N}^{\circ} 656$ de 1996, que desarrolla la Ley $\mathrm{N}^{\circ}$ 19.451, reitera este principio, especialmente, en su artículo 5:

La entrega de órganos para los fines de trasplante, sea que se realice entre vivos o por causa de muerte, es un acto de altruismo y de expresión de la solidaridad entre los hombres, de manera que debe efectuarse siempre a titulo gratuito y será nulo y sin ningún valor el acto o contrato que contenga la promesa o entrega de órganos a título oneroso. ${ }^{11}$

Estos preceptos, en definitiva, declaran que todas las conductas tendentes al trasplante de órganos humanos, incluida su donación, han de ser gratuitas. De modo que, en caso de ánimo de lucro en el proceso serían de aplicación los artículos 152 y 174 del Código Sanitario. ${ }^{12}$ El primero de ellos determina que [s]erá nulo y sin ningún valor el acto o contrato que, a título oneroso, contenga la promesa o entrega de un tejido o parte del cuerpo bumano para efectuar un injerto. Y el segundo, que [1] a infracción de cualquiera de las disposiciones de este Código o de sus reglamentos y de las resoluciones que dicten los Directores de los Servicios de Salud o el Director del Instituto de Salud Pública de

\footnotetext{
11 El artículo 26 del mismo Decreto, además, indica que: La internación de órganos provenientes de donantes ubicados fuera del territorio nacional solamente podrá realizarse por los hospitales y clínicas a que se refiere el articulo $3^{\circ}$ de este reglamento. Podrán también internar al país órganos, otras entidades vinculadas a las materias de que trata este reglamento, siempre que cuenten con una autorización especial, extendida por el Ministerio de Salud para este efecto. Ambas actividades serán realizadas siempre a titulo gratuito.

${ }^{12}$ El Código Sanitario, en el Título IX -Aprovechamiento de órganos, tejidos o partes del cuerpo de un donante vivo y de la utilización de cadáveres o partes de ellos con fines científicos o terapéuticos- $y$, particularmente, en los preceptos que se introdujeron mediante la Ley $\mathrm{N}^{\circ} 18.173$, de 1982, también prevé el principio de gratuidad. Concretamente, el artículo 145 declara que [e] $l$ aprovechamiento de tejidos o partes de cuerpo de un donante vivo, para su injerto en otra persona, sólo se permitirá cuando fuere a título gratuito y con fines terapéuticos. Este precepto era el que proclamaba la gratuidad en relación con los órganos humanos con anterioridad a la entrada en vigor de la Ley $\mathrm{N}^{\mathrm{o}}$ 19.451. Sin embargo, ahora resulta aplicable, exclusivamente, a tejidos y células.
} 
Moya - El tráfico de órganos humanos. Estudio de su sanción en la legislación chilena y española

Chile, según sea el caso, salvo las disposiciones que tengan una sanción especial, será castigada con multa de un décimo de unidad tributaria mensual hasta mil unidades tributarias mensuales. Las reincidencias podrán ser sancionadas hasta con el doble de la multa original [...].

Por tanto, en caso de tráfico de órganos humanos -entendido este en el sentido de comercio de órganos humanos- las sanciones administrativas previstas en la legislación chilena son, por un lado, la nulidad del contrato; y, por otro lado, la imposición de una multa. Además, de forma facultativa, puede procederse a la clausura de establecimientos, edificios, casas, locales o lugares de trabajo donde se haya cometido la infracción; a la cancelación de la autorización para su funcionamiento o a la de los permisos concedidos; a la paralización de obras; y al comiso, destrucción y desnaturalización de productos procedentes del tráfico de órganos humanos.

Pero este tipo de actividades no solo se ha sancionado administrativamente, sino que la propia legislación chilena que regula el trasplante de órganos -la Ley $\mathrm{N}^{\circ}$ 19.451- contiene dos tipos penales contra el tráfico de órganos humanos. ${ }^{13}$ Concretamente, se trata de los artículos 13 y 13 bis.

El primero de ellos dispone lo siguiente:

El que facilitare o proporcionare a otro, con ánimo de lucro, algún órgano propio para ser usado con fines de trasplante, será penado con presidio menor en su grado minimo. En la misma pena incurrirá el que ofreciere o proporcionare dinero o cualesquiera otras prestaciones materiales o económicas con el objeto de obtener para si mismo algún órgano o el consentimiento necesario para su extracción. Si las conductas señaladas en el inciso anterior fueren realizadas por cuenta de terceros, la pena se aumentará en dos grados.

Como se observa, este precepto contempla tres supuestos típicos distintos, en virtud de las conductas previstas, que serían:

a) facilitar o proporcionar a otro algún órgano propio,

b) ofrecer o proporcionar dinero para obtener para sí un órgano, y

c) realizar las conductas anteriores por cuenta de terceros.

Por lo que a los sujetos activos del delito se refiere, en el primer supuesto, equivalente a los actos tendentes a la venta de un órgano, este título ha de corresponder al donante del órgano, ya que se hace expresa referencia al "órgano propio" ${ }^{\prime 1}$. El segundo supuesto típico, correspondiente a los actos tendentes a la

\footnotetext{
13 De este modo, parece superada la laguna acerca de la que alertaba Novoa Monreal. Véase, al respecto NOVOA (1969).

${ }^{14}$ El castigo que recae sobre el donante podría cuestionar la impunidad de las autolesiones. De ahí que, en ocasiones, este tipo de medidas sean calificadas de autoritarias. En este sentido, Muñoz Conde entiende que se trata de un caso de autolesión o autopuesta en peligro y, por ello, califica la
} 
compra de un órgano, se ha previsto para sancionar al receptor del órgano, ya que se ha determinado que la obtención del mismo ha de ser "para sî". Y, finalmente, el tercer supuesto típico que prevé el artículo 13 de la Ley $\mathrm{N}^{\circ} 19.451$ sería aquel en el que el sujeto activo es un tercero -ni donante ni receptor del órgano objeto de trasplante-, que o bien ofrece o proporciona dinero para conseguir un órgano, o bien gestiona la venta de un órgano a un tercero.

En cuanto a las penas, los dos primeros supuestos expuestos prevén la pena de presidio menor en su grado mínimo. En cambio, cuando estas conductas tendentes a la compra o a la venta de un órgano las realice un tercero, la pena se aumentará en dos grados. ${ }^{15}$

Y en relación únicamente con los órganos procedentes de personas fallecidas, el artículo 13 bis de la Ley $\mathrm{N}^{\circ} 19.451$, en vigor desde enero del año 2010, no sólo sanciona penalmente la obtención o el trasplante de órganos cuando medie ánimo de lucro. ${ }^{16}$ Este tipo amplía su ámbito de punición, al determinar que:

\section{"El que extraiga órganos de un cadáver con fines de trasplante sin cumplir con las disposiciones de esta ley será penado con presidio menor en su grado minimo. En igual sanción incurrirá quien destine dichos órganos a un uso distinto al permitido por la presente ley o el Código Sanitario. La infracción a las normas contenidas en el artículo $3^{\circ}$ bis se sancionará con una multa de veinte a cincuenta unidades tributarias mensuales".}

Por tanto, distingue también tres situaciones típicas, que serían:

a) extraer un órgano de manera ilegal,

b) destinar los órganos ilegalmente extraídos a un uso distinto al permitido, e

c) infringir el artículo 3 bis de la propia Ley No 19.451.

tipificación del tráfico de órganos humanos de "paternalismo estatal moderado", en MUÑOZ CONDE (2013), p. 132.

Conviene advertir, en otros orden de cosas, que cuando en el trabajo aludo al "donante" estoy haciendo referencia a quien entrega el órgano, aunque sea vendiéndolo; y cuando aludo al "receptor" estoy haciendo referencia a quien lo recibe, aunque sea comprándolo. Utilizo, no obstante, los términos "donante" y "receptor", y no, por ejemplo, "vendedor" y "comprador", ya que es así como los utiliza la doctrina especializada en la materia y porque elegir la correspondiente calificación en algunos casos límite resulta sumamente controvertido (piénsese, por ejemplo, en los casos de donación incentivada).

15 Según el artículo 56 del Código penal chileno, la reclusión menor en su grado mínimo se corresponde con un periodo que oscila entre los 61 y los 540 días, y cuando dicha pena se aumente en dos grados, oscilará entre 3 y 5 años.

16 Este delito solo será aplicable cuando los hechos se hayan cometido con posterioridad al 15 de enero del 2010, fecha de entrada en vigor del delito, mediante la Ley $\mathrm{N}^{\circ} 20.413$, que modifica la Ley $\mathrm{N}^{\circ} 19.451$, con el fin de determinar quiénes pueden ser considerados donantes de órganos y la forma en que pueden manifestar su voluntad. 
Moya - El tráfico de órganos humanos. Estudio de su sanción en la legislación chilena y española

En este caso, la pena prevista también es la de presidio menor en su grado mínimo, excepto cuando se vulnere el artículo 3 bis de la Ley, en cuyo caso se sancionará con multa de veinte a cincuenta unidades tributarias mensuales. ${ }^{17}$

Como se observa, el artículo 13 bis contiene, al menos, dos normas penales en blanco, que se remiten al resto del articulado de la Ley $\mathrm{N}^{\circ} 19.451$, con los problemas en relación con el principio de legalidad que este hecho plantea. Así, conductas que, en relación con los órganos procedentes de personas fallecidas, fuesen contrarias a lo dispuesto, especialmente en el artículo 11 de esta ley especial serían constitutivas de delito, ${ }^{18}$ así como también el incumplimiento del artículo 3 bis, que expresamente se indica. ${ }^{19}$ En conclusión, se podría sancionar mediante la aplicación del artículo 13 bis de la Ley $\mathrm{N}^{\circ} 19.451$ a cualquiera que infrinja la normativa mencionada, incluido el receptor.

Pero teniendo en cuenta las disposiciones que sancionan el tráfico de órganos humanos, resulta conveniente plantearse cómo proceder en el caso de resultar aplicable a un mismo hecho tanto la legislación sancionadora administrativa como la penal. De este modo, podremos conocer la sanción a imponer si, por ejemplo, un enfermo acuerda la compra de un órgano para sí mediante un intermediario. En un caso como este, donante, receptor e intermediario habrían vulnerado la normativa administrativa en materia de

\footnotetext{
${ }^{17}$ La multa de veinte a cincuenta unidades tributarias mensuales equivaldría a una sanción de entre 740.000 y 1.800 .000 pesos chilenos, aproximadamente.

18 El artículo 11 de la Ley $\mathrm{N}^{0} 19.451$ contempla los requisitos exigidos para la extracción de órganos procedentes de personas fallecidas y, por ello, entiendo que el tipo penal remite a dicho precepto. Concretamente, el artículo 11 establece que:

Para los efectos previstos en esta ley, la muerte se acreditará mediante certificación unánime e inequivoca, otorgada por un equipo de médicos, uno de cuyos integrantes, al menos, deberá desempeñarse en el campo de la neurología o neurocirugía.

Los médicos que otorguen la certificación no podrán formar parte del equipo que vaya a efectuar el trasplante.

La certificación se otorgará cuando se haya comprobado la abolición total e irreversible de todas las funciones encefálicas, lo que se acreditará con la certeza diagnóstica de la causa del mal, según parámetros clínicos corroborados por las pruebas o exámenes calificados. El reglamento deberá considerar, como mínimo, que la persona cuya muerte encefálica se declara, presente las siguientes condiciones:

1.- Ningún movimiento voluntario observado durante una hora;

2.- Apnea luego de tres minutos de desconexión de ventilador, y

3.- Ausencia de reflejos troncoencefálicos.

En estos casos, al certificado de defunción expedido por un médico, se agregará un documento en que se dejará constancia de los antecedentes que permitieron acreditar la muerte.

${ }^{19} \mathrm{El}$ artículo 3 bis de la Ley $\mathrm{N}^{\circ} 19.451$, insertado mediante la Ley $\mathrm{N}^{\circ} 20.413$, de 2010, determina que: No podrán facilitarse ni divulgarse informaciones que permitan identificar al donante.

Asimismo, los familiares del donante no podrán conocer la identidad del receptor, ni el receptor o sus familiares la del donante y, en general, queda probibida cualquier difusión de información que pueda relacionar directamente la extracción con el ulterior injerto o implantación.

Esta probibición no afectará a los directamente interesados en una donación entre personas vivas.

La información relativa a donantes y receptores de órganos humanos será recogida, tratada y custodiada en la más estricta confidencialidad y se considerará un dato sensible, conforme a lo dispuesto en la ley $n^{\circ} 19.628$, sobre protección de la vida privada.
} 
REJ - Revista de Estudios de la Justicia - No 20 - Año 2014

trasplantes -concretamente, el principio de gratuidad-, y, además, serían penalmente responsables del delito de tráfico de órganos humanos.

El principio non bis in idem sería el principio de referencia para solucionar este tipo de conflictos entre normas. Este prohíbe que una misma persona sea sancionada dos veces por un mismo hecho cuando las sanciones alberguen idéntico fundamento. ${ }^{20}$ Sin embargo, en Chile, la aplicación de este principio es una cuestión debatida. ${ }^{21}$ Gran parte de la doctrina entiende que cuando se prevén sanciones administrativas y penales para un mismo hecho se están tratando de proteger bienes jurídicos distintos y, por tanto, permitiendo el cúmulo de responsabilidades. ${ }^{22}$ No obstante, bajo mi punto de vista, no debería establecerse un símil entre estos y los preceptos aquí analizados, ya que la sanción del tráfico de órganos humanos albergaría, como seguidamente trataré de justificar, idéntico fundamento en ambos órdenes -el penal y el administrativo-: la protección de la

${ }^{20}$ Sobre este principio, véase, entre otros, MAÑALICH (2011), pp. 139-169; NÁQUIRA, IZQUIERDO y VIDAL (2008). El principio non bis in idem formaría parte del ordenamiento jurídico chileno mediante el artículo 14.7 del Pacto Internacional de Derechos Civiles y Políticos; el artículo 8.4 de la Convención Americana sobre Derechos Humanos; y, los artículos 1.2, 13 y 264 del Código procesal penal.

21 Acerca de este debate, Ibíd. En él, adquiere especial importancia considerar que las diferencias entre la sanción administrativa y la penal radican en aspectos cualitativos o cuantitativos. En el primer caso, la aplicación acumulada de ambas sanciones se justificaría con mayor facilidad. En este sentido, NOVOA (1966), p. 121. En un sentido contrario, CURY (2005), p. 158.

${ }^{22}$ Este es el motivo por el que, por ejemplo, el artículo 162.3 del Código Tributario o el artículo 58 de la Ley del Mercado de Valores atribuyen carácter cumulativo a ambas sanciones. Esta postura también encuentra sustento en otros preceptos de la legislación chilena. Así, el artículo 133 de la Ley $\mathrm{N}^{\circ}$ 18.834, que desarrolla el estatuto administrativo, dispone que Cuando los hechos investigados y acreditados en el sumario pudieren importar la perpetración de delitos previstos en las leyes vigentes, el dictamen deberá contener, además, la petición de que se remitan los antecedentes a la justicia ordinaria, sin perjuicio de la denuncia que de los delitos debió hacerse en la oportunidad debida.

También en este sentido se manifiesta en el artículo 115 de la misma norma, que añade que La sanción administrativa es independiente de la responsabilidad civil y penal y, en consecuencia, las actuaciones o resoluciones referidas a ésta, tales como el archivo provisional, la aplicación del principio de oportunidad, la suspensión condicional del procedimiento, los acuerdos reparatorios, la condena, el sobreseimiento o la absolución judicial no excluyen la posibilidad de aplicar al funcionario una medida disciplinaria en razón de los mismos hechos. Si se le sancionare con la medida de destitución como consecuencia exclusiva de hechos que revisten caracteres de delito y en el proceso criminal bubiere sido absuelto o sobreseido definitivamente por no constituir delito los hechos denunciados, el funcionario deberá ser reincorporado a la institución en el cargo que desempeñaba a la fecha de la destitución o en otro de igual jerarquía. En este caso conservará todos sus derechos y beneficios legales y previsionales, como si hubiere estado en actividad.

En los demás casos de sobreseimiento definitivo o sentencia absolutoria, podrá pedir la reapertura del sumario administrativo y, si en éste también se le absolviere, procederá la reincorporación en los términos antes señalados.

Si no fuese posible llevar a la práctica la reincorporación en el plazo de seis meses, contado desde la absolución administrativa, el empleado tendrá derecho a exigir, como única indemnización por los daños y perjuicios que la medida disciplinaria le hubiere irrogado, el pago de la remuneración que le habría correspondido percibir en su cargo durante el tiempo que bubiere permanecido alejado de la Administración, hasta un máximo de tres años. La suma que corresponda deberá pagarse en un solo acto y reajustada conforme a la variación del indice de precios al consumidor, desde la fecha de cese de funciones hasta el mes anterior al de pago efectivo. 
salud pública. Por ello, teniendo en cuenta el principio non bis in idem, debería sancionarse la infracción por una sola vía, la penal, debido a que la antijuridicidad del delito absorbería la antinormatividad de la infracción administrativa. ${ }^{23}$

\section{i) Elementos controvertidos en la legislación penal relativa al tráfico de órganos humanos}

Los artículos 13 y 13 bis de la Ley $\mathrm{N}^{0}$ 19.451, que criminalizan el tráfico de órganos humanos, contienen algunos elementos, a mi juicio, controvertidos a los que quisiera referirme.

En primer lugar, el objeto material del delito, el "órgano humano", no ha sido definido en esta ley especial. Por ello, habría que interpretarlo según los criterios que proporcionan las organizaciones internacionales de las que Chile forma parte. En este sentido, la OMS define el "órgano humano" como una parte diferenciada y vital del cuerpo humano, formada por diferentes tejidos, que mantiene su estructura, vascularización y capacidad para desarrollar funciones fisiológicas con un nivel de autonomia importante. ${ }^{24}$ Así pues, quedarían excluidos del ámbito de aplicación de este tipo penal los tejidos y las células, cuyo tráfico ilegal se sancionaría exclusivamente por vía administrativa. ${ }^{25}$ Además, en este punto, sería conveniente precisar si este objeto material se circunscribe a los órganos procedentes de personas vivas o si también podrían comprenderse en él los órganos procedentes de personas fallecidas. Bajo mi punto de vista, en principio, de acuerdo con argumentos gramaticales, se pueden distinguir tres casos: el primer supuesto previsto en el artículo 13 se limitaría a los órganos procedentes de personas vivas; los dos últimos supuestos de este mismo tipo penal estarían aludiendo tanto a los órganos procedentes de personas vivas como de fallecidas; y los distintos supuestos típicos previstos en el artículo 13 bis se limitarían a los órganos procedentes de personas fallecidas.

En segundo lugar, en relación con el artículo 13, quisiera llamar la atención sobre el hecho de que se hayan excluido los siguientes supuestos. Por un lado, el referido artículo 13 ha dejado fuera de su alcance punitivo las conductas tendentes al trasplante de órganos efectuadas al margen de los cauces legalmente previstos al efecto cuando se realicen a título gratuito. Mediante esta decisión, si, por ejemplo, un receptor obtuviese ilegalmente un órgano para sí sin el consentimiento del donante, pero sin ofrecer ni proporcionar dinero a cambio del mismo, no se le podría sancionar en virtud de este tipo penal, ya que para la realización del mismo

\footnotetext{
${ }^{23}$ En defensa de esta posición, entre otros, CASTILLO (2009).

${ }^{24}$ Esta definición la proporciona la OMS en su publicación Global glossary of terms and definitions on donation and transplantation de 2009.

${ }^{25}$ En Chile, el tráfico de estos materiales anatómicos se sancionaría mediante la aplicación de los artículos 152 y 174 del Código Sanitario, expuestos con anterioridad.
} 
se requiere ánimo de lucro. ${ }^{26}$ Por otro lado, el mismo artículo 13 no contempla la posibilidad de castigar la comisión de las conductas previstas cuando se realicen con una finalidad distinta a la del trasplante. Por ello, si, por ejemplo, un donante vivo vendiese un órgano para que se investigase con el mismo o para que se realizase algún ritual no se le podría sancionar conforme a este tipo penal.

Finalmente, en relación con el artículo 13 bis, quisiera poner de manifiesto que, a pesar de que al elaborar este precepto parece que se pretendía castigar todo el ciclo del tráfico de órganos humanos procedentes de fallecidos, se ha obviado el alcance tan limitado que puede tener el mismo en dos de sus aspectos. El primer aspecto discutible, en mi opinión, es que este tipo penal no sanciona a quienes realicen los actos tendentes a la extracción del órgano, sino solo a quienes efectivamente lo extraigan. Ello provoca que la sanción quede limitada, en principio, al sujeto que realiza materialmente la extracción del órgano; es decir, al personal sanitario implicado en la intervención. En cambio, quedarían excluidos del tipo penal los intermediarios y otros agentes que hagan posible la compraventa del órgano o que incluso la promuevan. $\mathrm{Y}$ el segundo aspecto que resulta llamativo, en este contexto, es la limitación que contiene el segundo supuesto típico del precepto, que sanciona al que use ilegalmente los órganos que hayan sido extraídos de forma ilegal. ${ }^{27}$ No basta, por tanto, con utilizar un órgano a sabiendas de su origen ilícito; sino que, además, se exige que su uso sea distinto al previsto por la ley. ${ }^{28}$

\footnotetext{
${ }^{26}$ En este caso, no obstante, podría aplicarse, si se dan los elementos exigidos en el tipo, el delito de trata de personas con fines de extracción de órganos del artículo 411 quater del Código penal, que establece lo siguiente:

El que mediante violencia, intimidación, coacción, engaño, abuso de poder, aprovechamiento de una situación de vulnerabilidad o de dependencia de la víctima, o la concesión o recepción de pagos u otros beneficios para obtener el consentimiento de una persona que tenga autoridad sobre otra capte, traslade, acoja o reciba personas para que sean objeto de alguna forma de explotación sexual, incluyendo la pornografía, trabajos o servicios forzados, servidumbre o esclavitud o prácticas análogas a ésta, o extracción de órganos, será castigado con la pena de reclusión mayor en sus grados minimo a medio y multa de cincuenta a cien unidades tributarias mensuales.

Si la víctima fuere menor de edad, aun cuando no concurriere violencia, intimidación, coacción, engaño, abuso de poder, aprovechamiento de una situación de vulnerabilidad o de dependencia de la víctima, o la concesión o recepción de pagos $u$ otros beneficios para obtener el consentimiento de una persona que tenga autoridad sobre otra, se impondrán las penas de reclusión mayor en su grado medio y multa de cincuenta a cien unidades tributarias mensuales.

El que promueva, facilite o financie la ejecución de las conductas descritas en este artículo será sancionado como autor del delito.

${ }^{27} \mathrm{El}$ aprovechamiento de órganos del cuerpo de una persona fallecida solo se permite cuando sea con fines terapéuticos, de investigación científica, para la docencia universitaria o para la elaboración de productos terapéuticos (artículo 146 del Código Sanitario).

${ }^{28} \mathrm{Nada}$ impide, sin embargo, que ambos supuestos puedan sancionarse, en principio, con arreglo al artículo 13 de la Ley $\mathrm{N}^{\circ} 19.451$.
} 


\section{ii) Estudio de la Sentencia 6066/2010, de 12 de julio de 2011, del Juzgado de Garantía de Puente Alto}

En el contexto legislativo que acaba de ser descrito, la Sentencia 6066/2010, de 12 de julio de 2011, del Juzgado de Garantía de Puente Alto, ha sido la primera resolución condenatoria que se ha dictado en Chile por tráfico de órganos humanos.

La investigación de los hechos se inició a raíz de una denuncia, interpuesta en el año 2010, en la que se evidenció la falsificación del acta de donación de las córneas de un fallecido y su posterior extracción con fines de trasplante, sin cumplir con las disposiciones y autorizaciones exigidas en la Ley $\mathrm{N}^{0} 19.451{ }^{29}$

Tras la debida indagación, los hechos por los que finalmente fue condenado el sujeto imputado fueron doce delitos de falsificación de documentos auténticos y a su vez extracción ilegal de órganos, en grado de consumado, en concurso ideal mediático, cometidos los días 18 de marzo de 2008, 15 de mayo de 2008, 2 de junio de 2008, 18 de julio de 2008, 29 de agosto de 2008, 20 de mayo de 2009, 12 de noviembre de 2009, 20 de noviembre de 2009, 27 de noviembre de 2009, 17 de diciembre de 2009, 22 de enero de 2010 y 15 de abril de 2010, en la Comuna de Puente Alto.

Por todo ello se le condenó a la pena de tres años y un día de presidio menor en su grado máximo, a las accesorias de inhabilitación absoluta perpetua para derechos políticos, y a la inhabilitación absoluta para cargo y oficio público durante el tiempo de la condena. Sin embargo, finalmente, se le concedió el beneficio de la libertad vigilada, quedando sujeto al control de Gendarmería de Chile durante un periodo de 6 años. ${ }^{30}$

Esta sentencia resulta especialmente relevante no solo por su evidente novedad, sino también porque, bajo mi punto de vista, adopta decisiones sumamente discutibles. Así, por un lado, el sujeto condenado lo es por traficar con córneas de fallecidos, pero esta conducta debería haber sido sancionada administrativamente, y no mediante la aplicación del artículo 13 bis de la Ley $\mathrm{N}^{\circ}$ 19.451, que es el precepto aplicado. Este tipo penal, como he indicado con anterioridad, se limita a sancionar las conductas que tengan como objeto material los "órganos humanos", pero no los tejidos o las células; y las córneas no son órganos sino tejidos. ${ }^{31}$ Por otro lado, en esta sentencia se condena al sujeto por su

\footnotetext{
${ }^{29}$ En este sentido, ya en 1968 afirmó Rivacoba y Rivacoba que la córnea ofrece, además, dos ventajas: que puede extraerse hasta algunas horas después de la muerte del donante y conservarse fácilmente unas cuantas más, y que no requiere una minuciosa coincidencia entre sus características y las del paciente receptor. Pero en los de la otra especie del organismo produce unas substancias llamadas anticuerpos, hasta conseguir rechazar el órgano intruso, en RivaCOBA (1968), p. 245.

${ }^{30} \mathrm{La}$ libertad vigilada estaba prevista para sustituir penas privativas de libertad que oscilasen entre los 2 y los 5 años. Al respecto, véase la Ley $\mathrm{N}^{\circ} 18.216$ de 1983, que establece penas que indica como sustitutivas a las penas privativas o restrictivas de libertad.

${ }^{31}$ Este límite al objeto material de la Ley No 19.451 se confirma en el artículo 17 de la misma.
} 
responsabilidad como autor de doce delitos de extracción ilegal de órganos, cuando solo dos de ellos se produjeron con posterioridad a la entrada en vigor del artículo 13 bis de la Ley $\mathrm{N}^{\circ}$ 19.451; es decir, con posterioridad al 15 de enero de 2010.

\section{b) La legislación española sancionadora del tráfico de órganos humanos}

En España, el principio de gratuidad en materia de donación y trasplante de órganos humanos se proclama en la Ley 30/1979, de 27 de octubre, sobre extracción y trasplante de órganos (en adelante, Ley 30/1979), y se desarrolla en el Real Decreto 1723/2012, de 28 de diciembre, por el que se regulan las actividades de obtención, utilización clínica y coordinación territorial de los órganos humanos destinados al trasplante y se establecen requisitos de calidad y seguridad (en adelante, RD 1723/2012). ${ }^{32}$

La Ley 30/1979 establece el principio de gratuidad en el artículo 2:

No se podrá percibir compensación alguna por la donación de órganos. Se arbitrarán los medios para que la realización de estos procedimientos no sea en ningún caso gravosa para el donante vivo ni para la familia del fallecido. En ningún caso existirá compensación económica alguna para el donante, ni se exigirá al receptor precio alguno por el órgano trasplantado.

Y el RD 1723/2012 confirma el mismo principio rector, especialmente, en el artículo 7 , al determinar lo siguiente: ${ }^{33}$

\footnotetext{
32 En España, el principio de gratuidad, pero en relación con la donación y el trasplante de tejidos y células, se prevé en el Real Decreto 1301/2006, de 10 de noviembre, por el que se establecen las normas de calidad y seguridad para la donación, la obtención, la evaluación, el procesamiento, la preservación, el almacenamiento y la distribución de células y tejidos humanos y se aprueban las normas de coordinación y funcionamiento para su uso en humanos (en adelante, RD 1301/2006). Concretamente, el artículo 3 de esta norma establece que:

1. La donación de células y tejidos será, en todo caso, voluntaria y altruista, no pudiéndose percibir contraprestación económica o remuneración alguna ni por el donante ni por cualquier otra persona física ni jurídica.

2. Los procedimientos médicos relacionados con la extracción no serán, en ningún caso, gravosos para el donante vivo, ni para la familia en el caso del donante fallecido, debiendo garantizarse al donante vivo la asistencia precisa para su restablecimiento.

3. Los donantes vivos de células o tejidos podrán recibir una compensación de la institución responsable de la extracción, limitada, estrictamente, a cubrir los gastos e inconvenientes derivados de su obtención en concepto de dietas, restitución de ingresos económicos perdidos o similares.

4. No se exigirá al receptor contraprestación alguna por las células y/o tejidos utilizados.

5. Las actividades de los establecimientos de tejidos no tendrán carácter lucrativo, y exclusivamente podrán repercutirse los costes efectivos de los servicios prestados por el desarrollo de las actividades autorizadas.

33 También el artículo 4.2, que determina los principios fundamentales que rigen en materia de obtención y utilización clínica de los órganos humanos, prevé el principio de gratuidad en la materia (véase la nota 9).
} 
Moya - El tráfico de órganos humanos. Estudio de su sanción en la legislación chilena y española

1. No se podrá percibir gratificación alguna por la donación de órganos bumanos por el donante, ni por cualquier otra persona física o jurídica. Tampoco se podrán ofrecer o entregar beneficios pecuniarios o de cualquier otro tipo en relación con la asignación de uno o varios órganos para trasplante, así como solicitarlos o aceptarlos.

2. La realización de los procedimientos médicos relacionados con la obtención no será, en ningún caso, gravosa para el donante vivo ni para la familia del fallecido. El principio de gratuidad no impedirá a los donantes vivos el resarcimiento de los gastos y la pérdida de ingresos directamente relacionados con la donación. Cuando dicha restitución resulte procedente, habrá de efectuarse necesariamente a través de los mecanismos que se puedan prever a tal efecto por las administraciones competentes.

3. Se prohibe hacer cualquier publicidad sobre la necesidad de un órgano o sobre su disponibilidad, ofreciendo o buscando algún tipo de gratificación o remuneración.

4. No se exigirá al receptor precio alguno por el órgano trasplantado.

Por tanto, como en Chile, las sanciones administrativas previstas contra el tráfico de órganos humanos consisten, básicamente, en la nulidad del contrato y el pago de una multa. Así, el contrato por el que donante y receptor hubiesen acordado la compraventa del órgano sería nulo en virtud del artículo 6.3 del Código civil $;{ }^{34} \mathrm{y}$, además, se impondría una multa de hasta 600.000 euros, en virtud de lo dispuesto en los artículos 33 y 34 del propio RD 1723/2012, ya que la vulneración del principio de gratuidad constituye una infracción muy grave.

En el orden penal, en cambio, la vulneración del principio de gratuidad se ha tipificado en el artículo 156 bis del Código penal, con origen en la Ley Orgánica

\footnotetext{
${ }^{34}$ Por lo que se refiere a la nulidad del contrato, el artículo 6.3 del Código civil señala que los actos contrarios a las normas imperativas y a las probibitivas son nulos de pleno derecho, salvo que en ellas se establezca un efecto distinto para el caso de contravención. El mismo será de aplicación en coherencia con lo dispuesto en los artículos 1261 y 1271 del Código civil.

35 El artículo 33 del RD 1723/2012 recoge, entre las infracciones muy graves: la realización de cualquier actividad regulada en este real decreto sin respetar los principios de voluntariedad, altruismo, ausencia de ánimo de lucro o gratuidad; la publicidad sobre la necesidad o la disponibilidad de un órgano, ofreciendo o solicitando algún tipo de gratificación o remuneración; la obtención de órganos de donante vivo en ausencia de cumplimiento de cualquiera de los requisitos previos establecidos en el presente real decreto, en particular los relativos a la mayoría de edad, facultades mentales, estado de salud y consentimiento; y, la obtención de órganos de donante fallecido en ausencia cualquiera de los requisitos previos establecidos en el presente real decreto, en particular los relativos a la investigación sobre la voluntad del fallecido respecto a la donación de órganos y el diagnóstico y la certificación de la muerte.

Y el artículo 34 establece que [1] as infracciones a que se refiere el articulo 33 serán sancionadas con multa de acuerdo con la graduación establecida en el artículo 58 de la Ley 33/2011, de 4 de octubre, el artículo 45 de la Ley Orgánica 15/1999, de 13 de diciembre, y en el artículo 36 de la Ley 14/1986, de 25 de abril. El primero de estos preceptos prevé una multa de entre 60.001 y 600.000 euros en caso de infracción muy grave; el segundo, multa de entre 300.001 y 600.000 euros para este mismo caso; y el tercero, multa de entre 2.500.001 y 100.000.000 de pesetas, pudiendo rebasar dicha cantidad hasta alcanzar el quíntuplo del valor de los productos o servicios objeto de la infracción.
} 
REJ - Revista de Estudios de la Justicia - No 20 - Año 2014

5/2010, de 22 de junio, por la que se modifica la Ley Orgánica 10/1995, de 23 de noviembre, del Código penal.

El referido precepto establece que:

1. Los que promuevan, favorezcan, faciliten o publiciten la obtención o el tráfico ilegal de órganos humanos ajenos o el trasplante de los mismos serán castigados con la pena de prisión de seis a doce años si se tratara de un órgano principal, y de prisión de tres a seis años si el órgano fuera no principal.

2. Si el receptor del órgano consintiera la realización del trasplante conociendo su origen ilícito será castigado con las mismas penas que en el apartado anterior, que podrán ser rebajadas en uno o dos grados atendiendo a las circunstancias del hecho $y$ del culpable.

3. Cuando de acuerdo con lo establecido en el artículo 31 bis una persona jurídica sea responsable de los delitos comprendidos en este artículo, se le impondrá la pena de multa del triple al quintuple del beneficio obtenido.

Atendidas las reglas establecidas en el artículo 66 bis, los jueces y tribunales podrán asimismo imponer las penas recogidas en las letras b) a g) del apartado 7 del artículo 33.

Por tanto, en España se sancionan tanto las conductas tendentes a la obtención ilegal de órganos humanos ajenos como las dirigidas al tráfico ilegal de órganos humanos ajenos y las preordenadas al trasplante de órganos obtenidos ilegalmente o que procedan del tráfico ilegal. Así, se puede afirmar que el tipo penal español no sanciona exclusivamente el comercio de órganos humanos, sino que además incluye en su ámbito de punición la obtención ilegal de órganos humanos y su posterior trasplante, aunque se realicen gratuitamente. ${ }^{36}$ De este modo, por ejemplo, sería de aplicación este tipo penal en caso de obtención del órgano humano sin el consentimiento libre e informado exigido legalmente, aunque no medie ánimo de lucro.

En relación con los sujetos activos del delito, se prevé una elevada sanción para los terceros; es decir, para aquellos que no sean ni donante ni receptor del órgano -de 3 a 6 años si el órgano no fuese principal y de 6 a 12 si lo fuese- ${ }^{37} \mathrm{Y}$ el

\footnotetext{
${ }^{36}$ La referencia a la ilegalidad en este tipo penal obliga a acudir a la legislación administrativa en materia de trasplantes. Concretamente, habrían de tenerse en cuenta las disposiciones del RD $1723 / 2012$.

37 Por estas mismas conductas típicas de terceros también podrían responder penalmente las personas jurídicas (artículo 156 bis.3). Para ellas se ha previsto la pena de multa del triple al quíntuple del beneficio obtenido. Además, los jueces y tribunales podrán imponer las siguientes penas:

- Disolución de la persona jurídica, que producirá la pérdida definitiva de su personalidad jurídica, así como la de su capacidad de actuar de cualquier modo en el tráfico jurídico, o llevar a cabo cualquier clase de actividad, aunque sea lícita.

- Intervención judicial para salvaguardar los derechos de los trabajadores o de los acreedores por el tiempo que se estime necesario, que no podrá exceder de cinco años.
} 
Moya - El tráfico de órganos humanos. Estudio de su sanción en la legislación chilena y española

segundo inciso del tipo penal castiga al receptor del órgano si consiente la realización del trasplante conociendo el origen ilegal del órgano, aunque en este caso la pena de prisión prevista en el primer inciso se podrá rebajar en uno o dos grados. ${ }^{38}$ Por lo tanto, el donante es el único que queda al margen del delito al determinarse expresamente que el objeto material del mismo ha de ser un "órgano ajeno". ${ }^{39}$ Asimismo, recuérdese que este objeto material impide sancionar mediante la aplicación de este delito el tráfico de tejidos y células. ${ }^{40} \mathrm{Y}$, en todo caso, téngase en cuenta que solo un sector minoritario de la doctrina española estima que el tráfico de órganos humanos procedentes de personas fallecidas se incluya en el tipo penal. ${ }^{41}$

En España también puede plantearse, como exponía en relación con la legislación chilena, un concurso de normas entre la normativa administrativa y la penal sancionadora del tráfico de órganos humanos. ${ }^{42}$ En este caso, el principio non bis in idem emana de los artículos 9.3 y 25 de la Constitución, y se desarrolla en el artículo 133 de la Ley 30/1992, de 26 de noviembre, de Régimen Jurídico de las Administraciones Públicas y del Procedimiento Administrativo Común, así como en el artículo 7 del Real Decreto de 4 de agosto de 1993, sobre el ejercicio de la potestad sancionadora. ${ }^{43}$

\footnotetext{
${ }^{38}$ En relación con el segundo inciso del artículo 156 bis del Código penal español, véase, entre otros, Alemán (2012), pp. 96-107; RomeO (2010), p. 179; y Alastuey (2013), p. 20.

39 Sobre la ausencia de pena para el donante, véase, GÓMEZ RIVERO (2013), pp. 129-133. También sobre ello, MUÑOZ CONDE (2013), pp. 120-125.

${ }^{40}$ En el artículo 3 del RD 1723/2012 se determina que "órgano" es aquella parte diferenciada del cuerpo bumano constituida por diversos tejidos que mantiene su estructura, vascularización y capacidad para desarrollar funciones fisiologicas con un grado importante de autonomía y suficiencia. Son, en este sentido, órganos: los riñones, el corazón, los pulmones el hígado, el páncreas, el intestino y cuantos otros con similar criterio puedan ser obtenidos y trasplantados de acuerdo con los avances cientificos y técnicos. Se considera asimismo órgano, la parte de éste cuya función sea la de ser utilizada en el cuerpo bumano con la misma finalidad que el órgano completo, manteniendo los requisitos de estructura y vascularización. A efectos de este Real Decreto, también se considerarán órganos los tejidos compuestos vascularizados. Y el RD 1301/2006 define los "tejidos" como toda parte constituyente del cuerpo bumano formada por células unidas por algún tipo de tejido conectivo; y las "células" como las células individuales de origen bumano o los grupos celulares de origen bumano cuando no estén unidos por ninguna forma de tejido conectivo.

${ }^{41}$ Entre los autores que consideran que los órganos procedentes de personas fallecidas se incluyen en el objeto material del delito del artículo 156 bis del Código penal, ALASTUEY (2013) y GómEZ RIVERO (2013).

42 Acerca de estos conflictos, García Albero (1995).

${ }^{43} \mathrm{El}$ artículo 133 de la Ley 30/1992 determina que [n]o podrán sancionarse los hechos que hayan sido sancionados penal o administrativamente, en los casos en que se aprecie identidad del sujeto, becho y fundamento; y el artículo 7 del Real Decreto de 4 de agosto de 1993, que:

1. En cualquier momento del procedimiento sancionador en que los órganos competentes estimen que los hechos también pudieran ser constitutivos de ilicito penal, lo comunicarán al Ministerio Fiscal, solicitándole testimonio sobre las actuaciones practicadas respecto de la comunicación.

En estos supuestos, asi como cuando los órganos competentes tengan conocimiento de que se está desarrollando un proceso penal sobre los mismos hechos, solicitarán del órgano judicial comunicación sobre las actuaciones adoptadas.
} 
No obstante, por su especialidad, conviene tener en cuenta el contenido del artículo 34.1 del propio RD 1723/2012, ya que este es el que establece el procedimiento a seguir en caso de concurso de normas en esta materia:

Las acciones u omisiones constitutivas de infracción, de acuerdo con lo establecido en el artículo 33, podrán ser objeto de la sanción administrativa prevista en el número 3 del presente articulo, previa instrucción del oportuno procedimiento sancionador, sin perjuicio de las responsabilidades penales, civiles o de otro tipo que pudieran concurrir.

En los supuestos en que las infracciones pudieran ser constitutivas de delito, se pasará el tanto de culpa a la jurisdicción competente y se abstendrá de seguir el procedimiento sancionador mientras la autoridad judicial no dicte resolución firme que ponga fin al procedimiento.

De no haberse estimado la existencia de delito, se continuará el expediente sancionador tomando como base los hechos que los Tribunales hayan considerado probados.

En definitiva, la legislación española determina que cuando la jurisdicción penal conozca de un caso de tráfico de órganos humanos, se suspenderá el procedimiento administrativo que se hubiese iniciado, si media la triple identidad de sujeto, hecho y fundamento. Además, si finalmente se impone la correspondiente pena, no habrá sanción administrativa. ${ }^{44}$

\section{i) Breve reflexión acerca del bien jurídico protegido en el delito de tráfico de órganos humanos}

La cuestión sobre el bien jurídico protegido en este tipo penal español, como en las figuras delictivas vigentes en Chile en relación con el tráfico de órganos humanos, deviene imprescindible, especialmente, por las consecuencias que de su determinación se derivan, particularmente, para fijar las relaciones concursales con los delitos de lesiones. ${ }^{45}$

2. Recibida la comunicación, y si se estima que existe identidad de sujeto, becho y fundamento entre la infracción administrativa y la infracción penal que pudiera corresponder, el órgano competente para la resolución del procedimiento acordará su suspensión hasta que recaiga resolución judicial.

3. En todo caso, los hechos declarados probados por resolución judicial penal firme vinculan a los órganos administrativos respecto de los procedimientos sancionadores que substancien.

${ }^{44} \mathrm{Al}$ respecto, SANZ (2000), pp. 545-572.

45 Tanto en Chile como en España se sanciona penalmente, entre los delitos de lesiones, la extracción del órgano de persona viva cuando esta se realiza al margen de la normativa en materia de trasplantes. En España, esta se sancionaría mediante la aplicación de los artículos 149 o 150 del Código penal; y en Chile, mediante la aplicación del artículo 396 del Código Penal. 
El debate se centra en si el interés tutelado, en estos casos, es la salud individual, la salud pública, o si se trataría de un delito pluriofensivo. ${ }^{46}$ De este modo, si en el delito de tráfico de órganos humanos se considera protegida la salud individual, en caso de extraer el órgano ilegalmente o con fines comerciales sería de aplicación, exclusivamente, el correspondiente delito de lesiones, que absorbería al de tráfico de órganos humanos porque los actos constitutivos de este último quedarían consumados como estadios previos de la conducta efectivamente llevada a cabo con la extracción del órgano. En cambio, si en el delito de tráfico de órganos humanos se entiende protegida la salud pública, en caso de producirse las lesiones inherentes a la extracción del órgano en el contexto del tráfico de órganos humanos estaríamos ante un concurso ideal, o incluso medial, de delitos entre el delito de lesiones y el delito de tráfico de órganos humanos. ${ }^{47}$

A favor de la salud pública como el bien jurídico en el delito del artículo 156 bis del Código penal existen diversos argumentos. Entre ellos, conviene subrayar los siguientes: primero, que si se estuviese protegiendo exclusivamente la salud del donante, el delito de tráfico de órganos humanos resultaría desproporcionado, ya que lo que serían actos preparatorios de los delitos de lesiones se estarían castigando con las mismas penas previstas para la propia lesión -artículos 149 y 150 del Código Penal- y lo que serían conductas de mera complicidad se estarían castigando como conductas de autoría; segundo, que la salud individual ya se tutelaba suficientemente entre los delitos de lesiones, y que si este fuese también aquí el bien jurídico protegido, la norma sería meramente

\footnotetext{
${ }^{46}$ La salud individual como el bien jurídico protegido en el delito de tráfico de órganos humanos es defendida, en España, por BENÍTEZ (2011), pp. 115-125; GARCíA AlBERo (2010), pp. 141-149; y GÓmeZ MARTín (2011), pp. 369-370. Y en Chile, es defendida por PÉREZ (1998), p. 49, que añade que las valoraciones sociales respecto del cadáver en el caso de trasplantes por causa de muerte constituiría el bien jurídico protegido en el delito de tráfico de órganos humanos procedentes de personas fallecidas. También en este sentido, PASTEN y VALENCIA (2007), p. 68.

En defensa de la salud pública como el bien jurídico protegido en el delito de tráfico de órganos humanos, en España, particularmente, ALASTUEY (2013), pp. 8-13; y GÓMEZ RIVERO (2013), pp. 117-123. En Chile, durante la tramitación de la Ley No 20.413, de 2010, se ha afirmado, en esta dirección, que la salud pública sería el bien jurídico protegido en estos delitos. Esta afirmación aparece, concretamente, en el Segundo Informe de las Comisiones de Constitución, Legislación, Justicia y Reglamento y de Salud, unidas, recaído en el Proyecto de ley, en primer trámite constitucional, que modifica la Ley 19.451, con el fin de determinar quiénes pueden ser considerados donantes de órganos y la forma en que pueden manifestar su voluntad (Boletín $\mathrm{N}^{\circ}$ 4.999-11), de 6 de agosto de 2009. Según se afirma en este informe, el bien jurídico, en este caso, estaría vinculado al adecuado funcionamiento del sistema y, por ello, se entiende lógico que se extienda la punición solo a aquellas conductas que ostenten un ánimo de lucro, pues, más allá del desvalor de acción involucrado, ellas producen una clara distorsión en un sistema de donación de órganos que en su esencia es a título gratuito.

Finalmente, sostienen que se trata de un delito pluriofensivo, en España, MARTíN-CARO (2010), p. 1099; y CARRASCO (2011), pp. 259-279. Y en Chile, SEGOVIA y URBINA (1999), pp. 78-82 y 94.

47 Conviene tener en cuenta que la discusión acerca del bien jurídico protegido en los delitos analizados pone en duda la legitimidad de los mismos y, concretamente, su necesidad. Al respecto, DE LA CUESTA (2013).
} 
simbólica o propagandística; tercero, que si se hubiese querido proteger la salud del donante hubiese sido conveniente incluir esta figura penal entre los delitos que se benefician de la cláusula atenuatoria del artículo 155 del Código penal; y cuarto, que el delito de tráfico de órganos humanos no castiga exclusivamente los actos tendentes a la obtención ilegal de órganos, que son los que, en determinados casos, pondrían en peligro la salud del donante, sino que también sanciona los actos tendentes al tráfico ilegal de órganos y al trasplante de los mismos.

Por ende, me adhiero a aquel sector doctrinal que defiende que la salud pública es el interés tutelado en el delito de tráfico de órganos humanos. Este bien jurídico colectivo equivaldría, en este ámbito, a la salud de los potenciales donantes y receptores de órganos, para cuya protección se exige el adecuado funcionamiento del sistema nacional de trasplantes basado en los principios de gratuidad, voluntariedad y equidad.

\section{ii) Análisis de las conductas previstas en el artículo 156 bis del Código penal}

Teniendo en cuenta que, a mi juicio, el bien jurídico protegido en el delito de tráfico de órganos humanos sería la salud pública, a continuación voy a tratar de delimitar el alcance de las conductas típicas previstas.

El artículo 156 bis del Código Penal es un tipo mixto alternativo que castiga, como se ha podido observar, hasta 4 conductas -promover, favorecer, facilitar o publicitar- asociadas a alguno de estos tres comportamientos de referencia: la obtención ilegal de órganos humanos ajenos, el tráfico ilegal de órganos humanos ajenos o el trasplante de los mismos. Por tanto, basta con que se lleve a cabo cualquiera de las conductas en relación con alguno de los comportamientos para que se considere realizado el tipo.

De este modo, en el delito de tráfico de órganos humanos se sanciona a los que:

a) Promuevan, favorezcan, faciliten o publiciten la obtención ilegal de órganos humanos ajenos.

b) Promuevan, favorezcan, faciliten o publiciten el tráfico ilegal de órganos humanos ajenos.

c) Promuevan, favorezcan, faciliten o publiciten el trasplante de órganos procedentes de la obtención ilegal o procedentes del tráfico ilegal. ${ }^{48}$

Los verbos típicos "promover", "favorecer" y "facilitar" vendrían a comprender todos aquellos actos que contribuyen de alguna manera a la obtención o al tráfico

\footnotetext{
${ }^{48}$ En este mismo sentido, Carrasco (2011), p. 269.
} 
Moya - El tráfico de órganos humanos. Estudio de su sanción en la legislación chilena y española

ilegal de órganos humanos ajenos, o al trasplante de los mismos. ${ }^{49}$ Sin embargo, esta amplia previsión, que encontraría su razón de ser, como ocurre en el delito de tráfico de drogas, en la intención del legislador de castigar, en este caso, todo el ciclo del tráfico de órganos humanos, ${ }^{50}$ pone en cuestión el respeto al principio de legalidad y complica el análisis del tipo al castigar actos preparatorios y de ejecución imperfecta junto a los de consumación. ${ }^{51}$ De este modo, puede entenderse que promueve, favorece o facilita tanto el intermediario que pone en contacto a un receptor con una clínica en el extranjero dedicada al turismo de trasplantes, como quien recluta al donante, quien lo traslada, quien practica la operación, etcétera.

En cambio, la inclusión del verbo típico "publicitar", que respondería a la demanda de diversas organizaciones internacionales, ${ }^{52}$ ha sido aceptada con satisfacción por parte de la doctrina española por constituir un importante instrumento comisivo en este tipo de prácticas, debido a las facilidades que ofrecen las nuevas tecnologías de la comunicación para poner en contacto a personas interesadas en la realización de esas actividades. ${ }^{53}$ No obstante, publicitar la venta

\footnotetext{
49 Puesto que el verbo típico "facilitar" tiene la enorme ventaja de absorber todas las demás modalidades típicas, no se entiende que el legislador se moleste en acompañarlo de esta retahíla de verbos típicos. Al respecto, DE LA CUESTA (2013), p. 43.

${ }^{50}$ Hace referencia a la similitud entre este delito y el de tráfico de drogas, por las conductas típicas previstas, entre otros, MARTín-CARO (2010), p. 1100. Ha de tenerse en cuenta que, además, el artículo 451 del CP sanciona el encubrimiento de todas estas conductas típicas.

51 Pone de manifiesto los problemas que esta amplia previsión alberga, entre otros, CARRASCO (2011), p. 269. En cambio, la profesora Gómez Rivero entiende que si bien en éste como en tantos otros delitos en los que el legislador recurre a esta técnica de equiparación de las diversas contribuciones el juicio que merece es como regla general negativo, por cuanto desconoce los criterios que en general inspiran la graduación de la pena en el orden penal, hay que reconocer que aquellas críticas deben necesariamente matizarse a la vista de las peculiaridades del objeto de protección en el delito que ahora nos interesa. En efecto, si se parte, como aqui hacemos, de que el articulo 156 bis protege un bien jurídico que enlaza con la preservación de las condiciones bajo las cuales puede considerarse lícita la secuencia que media desde la extracción al trasplante de un órgano, parece lógico que la acción tipica no se agote en la efectiva realización de las conductas con mayor peso en la producción de un resultado, sino que de forma general se extienda a la práctica de las que, también con carácter previo, suponen una alteración de aquellas condiciones esenciales para garantizar la calidad y seguridad del proceso. El peso se hace recaer, en definitiva, en el desvalor de acción y no en el de resultado. De hecho, según tendremos ocasión de poner de relieve al ocuparnos de los sujetos del delito, esta misma razón explica que se equiparen en pena las contribuciones de autoría con aquellas otras que en principio representarian tan solo una forma de participación, en GÓMEZ RIVERO (2013), p. 126.

${ }^{52}$ La Resolución 63.22 de la OMS de 2010 sobre el trasplante de órganos y tejidos humanos señala que se permitirá la promoción de la donación altruista de células, tejidos u órganos humanos mediante publicidad o llamamiento público, de conformidad con la reglamentación nacional. Deberá probibirse toda publicidad sobre la necesidad o la disponibilidad de células, tejidos $u$ órganos cuyo fin sea ofrecer un pago a individuos por sus células, tejidos $u$ órganos, o a un pariente cercano en caso de que la persona baya fallecido o bien recabar un pago por ellos. Deberán probibirse asimismo los servicios de intermediación que entrañen el pago a esos individuos o a terceros (artículo 6).

${ }^{53}$ Destaca su conveniencia, por ejemplo, GómEz Rivero (2013), p. 126. En este sentido, García Albero afirma que mención especial merece la incriminación de la publicidad ya que han sido fundamentalmente las facilidades que ofrece Internet las que han convertido el tráfico y el turismo de trasplantes en un problema global, en GARCía AlBERO (2010), p. 145.
} 
del propio órgano quedará fuera del tipo, porque todos los actos que se sancionan han de ir referidos a órganos humanos "ajenos".

En cualquier caso, estas cuatro conductas típicas - promover, favorecer, facilitar o publicitar- han de referirse a la obtención ilegal de órganos humanos ajenos, al tráfico ilegal de órganos humanos ajenos o al trasplante de los mismos. Y es a la hora de delimitar estas tres situaciones cuando se plantean mayores dificultades. Sobre todo, resulta muy problemática, por un lado, la interpretación del adjetivo "ilegal" que sigue a cada uno de estos supuestos y, por otro lado, la delimitación de la intención que deben perseguir este tipo de comportamientos.

Sobre el primer aspecto problemático al que aludo se han venido defendiendo dos posiciones doctrinales distintas. La primera, defendida por los autores que entienden que la "ilegalidad" requerida tanto en la obtención de órganos como en el tráfico hace referencia al ánimo de lucro que ha de mediar en los mismos $;{ }^{54}$ y la segunda, por los que sostienen que dicha "ilegalidad" se refiere a cualquier vulneración de la normativa en materia de trasplantes -no solo a la del principio de gratuidad-. Los partidarios de esta última postura consideran, por tanto, que esta sería una norma penal en blanco. ${ }^{55}$

Bajo mi punto de vista, ya que el legislador no exige que medie contraprestación económica alguna, la obtención o el tráfico ilegal de órganos humanos ajenos serían los realizados al margen de la legislación en materia de trasplantes. No obstante, lo cierto es que, desde un punto de vista criminológico, en la mayoría de los casos el móvil de estas prácticas será económico. ${ }^{56}$

Y el segundo de los aspectos problemáticos que guardan en común los tres supuestos previstos en el artículo 156 bis del Código penal se refiere a si los comportamientos previstos han de ir preordenados a alguna finalidad concreta. En este caso, entiendo que, además del dolo, tanto en la obtención ilegal de órganos humanos ajenos como en su tráfico ilegal habría de concurrir un elemento subjetivo adicional: la intención de que el órgano sea trasplantado. ${ }^{57}$ Por ello, quedarían fuera del tipo las conductas que se dirigiesen, por ejemplo, a fines docentes, de investigación o a la realización de rituales. En todos estos supuestos, habría que acudir a los correspondientes delitos de homicidio, asesinato, lesiones, coacciones o profanación de cadáveres, según el caso, pero no al de tráfico de órganos humanos, a la vista del interés que se pretende salvaguardar.

\footnotetext{
54 En este sentido, Gómez Martín (2011), p. 370; y CARrasco (2011), pp. 269 y 270. Estos autores defienden, en definitiva, que por obtención ilegal ha de entenderse la compra de órganos; y por tráfico ilegal, la venta de los mismos.

55 Se adhieren a esta segunda comprensión, MARTín-CARO (2010), p. 1100; y PUENTE (2011), p. 146.

${ }^{56}$ Sobre ello, Aguado (2010), p. 165.

57 En defensa de este mismo elemento subjetivo del injusto, GómEZ RIVERO (2013), p. 124; y BENÍTEZ (2011), p. 121.
} 


\section{Conclusiones}

Expuesta y analizada la normativa sancionadora del tráfico de órganos humanos en Chile y en España, resumiré la similitud que guardan las disposiciones administrativas expuestas y, seguidamente, las diferencias mayúsculas que alejan los tipos penales chilenos del español.

Así, en relación con la legislación administrativa, existen ciertos aspectos comunes entre ambos ordenamientos jurídicos que considero relevantes. $\mathrm{Me}$ refiero a que las normas que prohíben el ánimo de lucro en el proceso tendente al trasplante de órganos son similares en ambos países. Y, además, ambos ordenamientos prevén análogas consecuencias jurídicas en caso de infracción de dicha normativa, que serían, principalmente, la nulidad del contrato de compraventa y la multa.

En cambio, la legislación penal sancionadora del tráfico de órganos humanos contiene diversos elementos que alejan la forma en que ambos ordenamientos jurídicos hacen frente al problema. ${ }^{58}$ Estas se centran, fundamentalmente, en cuatro aspectos: la ubicación de estos tipos penales, las conductas típicas, los sujetos activos y las penas previstas al efecto.

La primera diferencia entre la legislación penal chilena y la española consistiría en que la sanción del tráfico de órganos humanos en Chile se ha previsto en una ley especial -la Ley $\mathrm{N}^{\circ}$ 19.451-; mientras que, en España, se ha insertado en el Código penal.

La segunda, referida a las conductas típicas, residiría en que mientras la legislación chilena solo castiga penalmente el tráfico de órganos humanos procedentes de personas vivas si existe ánimo de lucro -artículo 13 de la Ley $\mathrm{N}^{\circ}$ 19.451-; el artículo 156 bis del Código penal español incluye entre las conductas típicas la obtención ilegal del órgano y su trasplante, aunque no medie ánimo de lucro. ${ }^{59}$

\footnotetext{
58 Ambas legislaciones también albergarían notas comunes, aunque en menor medida. Me refiero al objeto material y al bien jurídico protegido. Tanto los preceptos chilenos que tipifican el tráfico de órganos humanos como el español limitan su ámbito de punición al tráfico de órganos humanos, sin extenderlo al tráfico de tejidos y células. Por tanto, el objeto material en todos estos delitos es el mismo. Y, en relación con el bien jurídico protegido, lo que comparten ambos ordenamientos jurídicos es la incertidumbre sobre su determinación.

59 Sin embargo, en relación con los órganos procedentes de fallecidos, el artículo 13 bis de la Ley $\mathrm{N}^{\circ}$ 19.451, del mismo modo que el artículo 156 bis del Código penal español, elude exigir el requisito del ánimo de lucro. El tipo sanciona determinadas conductas que serán típicas por vulnerar la normativa en materia de trasplantes - constituyen, como se ha apuntado, leyes penales en blanco-.
} 
La tercera diferencia, en relación con los sujetos activos, radicaría en que mientras la legislación chilena prevé sanciones específicas para el donante, el receptor y los terceros; la española, excluye expresamente a los donantes del tipo penal.

Y, finalmente, la cuarta y última diferencia que considero importante señalar en este contexto, son las penas previstas por el ordenamiento jurídico chileno y las previstas por el español. Así, mientras en Chile las sanciones pueden llegar hasta los 5 años de prisión, pero encuentran el límite mínimo en los 61 días; en España se prevén sanciones mucho más severas, que oscilan entre los 3 y los 12 años de prisión.

Por tanto, visto el resultado de este análisis comparado de las legislaciones sancionadoras del tráfico de órganos humanos en Chile y España, convendría plantearse, entre otras cuestiones, si no hubiese sido mejor limitar el alcance de las conductas típicas previstas a aquellas actividades que pudiesen suponer un verdadero peligro para la salud pública, así como rebajar las penas de prisión previstas en los casos de tráfico de órganos procedentes de personas fallecidas, para garantizar los principios de legalidad y proporcionalidad, respectivamente. Además, aunque considero conveniente castigar al donante y al receptor por su implicación en los hechos, entiendo que sería imprescindible tener en cuenta la posibilidad de atenuarles la pena o incluso eximirles de ella, tal y como ha estipulado la alemana Transplantationsgesetz- TPG. 
Moya - El tráfico de órganos humanos. Estudio de su sanción en la legislación chilena y española

\section{BIBLIOGRAFÍA}

* Aguado López, Sara (2010): “Tráfico de órganos humanos", en Boix Reig, Javier (dir.), Derecho penal. Parte especial, Vol. 1 (Madrid, Iustel), pp. 163-166.

* Alastuey Dobón, Carmen (2013): “Aspectos problemáticos del delito de tráfico de órganos humanos", Revista penal (No 32/2013), pp. 3-23.

* Alemán López, Miguel Ángel (2012): "Una breve consideración sobre la excesiva penalidad establecida para el receptor de órganos humanos en el nuevo artículo 156 bis del Código penal”, La ley penal (No 94-95/2012), pp. 96-107.

* Benítez Ortúzar, Ignacio Francisco (2011): "Obtención, tráfico y trasplante ilícito de órganos humanos”, en Morillas Cuerva, Lorenzo (coord.), Sistema de Derecho penal español. Parte especial (Madrid, Dykinson), pp. 115-125.

* Boletín N $\mathrm{N}^{\mathrm{4}}$ 4.999-11, de 6 de agosto de 2009, Informe de las Comisiones de Constitución, Legislación, Justicia y Reglamento y de Salud, unidas, recaído en el Proyecto de ley, en primer trámite constitucional, que modifica la Ley 19.451, con el fin de determinar quiénes pueden ser considerados donantes de órganos y la forma en que pueden manifestar su voluntad.

* Carrasco Andrino, María del Mar (2011): "Tráfico de órganos y comercio de trasplantes”, en Álvarez García, Francisco Javier (dir.), Derecho penal español. Parte especial (I) (Valencia, Tirant lo Blanch), pp. 259-276.

* Castillo Vera, Francisco Victorino (2009): "Vulneración del principio non bis in idem en el sistema de sanciones estatales (penales y administrativas). Inaplicabilidad por inconstitucionalidad", Microjuris, ( $\mathrm{N}^{\circ}$ MJD321/2009), disponible en:

bttp:/ / www.bcbabogados.cl/images/Vulneracion.pdf (última consulta: 15/01/2014).

* CONSEjO DE EUROPA y ONU (2009): Joint Study "Trafficking in organs, tissues and cells and trafficking in human beings for the purpose of the removal organs".

* CONSEjO DE Europa (2012): Newsletter Transplant (Vol. 17, No 1), disponible en: bttp:// www.organdonor.gov/index.html (última consulta: 23/12/2013)

* Consejo de Europa (2013): Newsletter Transplant, (Vol. 18, No 1)

* Cury, Enrique (2005): Derecho Penal, Parte General (Santiago de Chile, Ediciones Universidad Católica de Chile).

* De la Cuesta Aguado, Paz Mercedes (2013): Delitos de tráfico ilegal de personas, objetos y mercancias (Valencia, Tirant lo Blanch).

* García Albero, Ramón (2010): “El nuevo delito de tráfico de órganos”, en Quintero Olivares, Gonzalo (dir.), La Reforma penal de 2010: Análisis y Comentarios (Navarra, Aranzadi), pp. 141-149. Editorial) (1995): Non bis in idem. Material y concurso de leyes penales (Barcelona, Cedecs

* Gómez Martín, Víctor (2011): “Artículo 156 bis”, en Corcoy Bidasolo, Mirentxu y Mir Puig, Santiago (dir.), Comentarios al Código Penal. Reforma LO 5/2010 (Valencia, Tirant lo Blanch), pp. 369-370.

* Gómez Rivero, María del Carmen (2013): "El delito de tráfico ilegal de órganos humanos", Revista penal (No 31/2013), pp. 113-133.

* Mañalich Raffo, Juan Pablo (2011): "El principio ne bis in idem en el Derecho penal chileno", Revista de Estudios de Justicia (No 15/2011), pp. 139-169.

* Martín-Caro Sánchez, José Antonio (2010): “De las lesiones. Artículo 156 bis", en Sánchez Melgar, Julián (coord.), Código Penal. Comentarios y jurisprudencia. Tomo I (Granada, Sepin), pp. 1098-1100.

* Muñoz Conde, Francisco (2013): “Tráfico de órganos", en del mismo, Derecho penal. Parte especial (Valencia, Tirant lo Blanch), pp. 120-125. 
REJ - Revista de Estudios de la Justicia - No 20 - Año 2014

* NÁquira, Jaime, IZQuierdo, Cristóbal y VIDAL, Víctor (2008): "Principios y penas en el Derecho penal chileno", Revista Electrónica de Ciencia Penal y Criminología (No 10-r2/2008).

* Novoa Monreal, Eduardo (1969): El trasplante de corazón en sus aspectos médico-legales, éticos y jurídicos (Santiago de Chile, Editorial Universitaria).

* Novoa Monreal, Eduardo (1966): Curso de Derecho penal chileno (Santiago de Chile, Editorial Jurídica de Chile).

* Observatorio Global Sobre Donaciones y Trasplantes (2010): Final Report on Organ Donation and Transplantation Activities, Laws and Organisations, disponible en: http:/ / www.transplant-observatory.org/Documents/Data\%20Reports/2010ReportFinal.pdf (última consulta: 16/12/2013).

* OMS (2010): Resolución 63.22 de 2010, sobre el trasplante de órganos y tejidos humanos.

* OMS (2009): Global glossary of terms and definitions on donation and transplantations.

* ONU (2006): Informe "Prevención, lucha y sanciones contra el tráfico de órganos humanos" del $15^{\circ}$ periodo de sesiones de la Comisión de Prevención del Delito y Justicia Penal, del Consejo Social y Económico, 2006 (E/CN.15/2006/10).

* Pastén SaAvedra, Romina y VAlencia Soissa, Bárbara (2007): Ley número 19.451, que establece normas sobre Trasplante y Donación de órganos y sus tipos penales (Santiago de Chile, Universidad Andrés Bello).

* Pérez Ramírez, Paz (1998): Análisis sobre las implicancias jurídicas y prácticas de la ley sobre trasplante y donación de órganos (Santiago de Chile, Universidad Diego Portales).

* Puente ABA, Luz María (2011): "La protección frente al tráfico de órganos: su reflejo en el Código penal”, Revista Derecho y proceso penal (No 26/2011) pp. 135-151.

* Red/Consejo iberoamericano De Donación Y Trasplante (2008): Recomendación 2008 (8), Consideraciones bioéticas sobre la donación y el trasplante de órganos, tejidos y células.

* Red/Consejo Iberoamericano De Donación Y Trasplante (2005): Declaración de Mar del Plata.

* Rivacoba Y Rivacoba, Manuel (1968): "Los trasplantes de órganos humanos ante el Derecho penal", Revista de ciencias penales, pp. 239-250.

* Romeo Casabona, Carlos María (2010): "La prohibición del tráfico ilegal y la exclusión de la comercialización de los órganos y tejidos", Revista Aranzadi doctrinal (No 7/2010), pp. 171-180.

* SANZ Rubiales, Íñigo (2000): "Potestad sancionadora administrativa, non bis in idem y primacía del orden penal (comentarios a la STC 177/1999, de 11 de octubre)", Revista del Poder Judicial ( $\mathrm{N}^{\circ}$ 59/2000), pp. 545-572.

* Segovia Molina, Cinthia Angélica y Urbina Herbias, Marcela (1999): Análisis de la Ley 19.451 y su Reglamento en cuando al concepto de muerte y a la extracción de órganos y tejidos desde cadáveres y los ilícitos penales en ella contenidos (Santiago de Chile, Universidad Andrés Bello).

* Sociedad del Trasplante (2008): Declaración de Estambul sobre el tráfico de órganos y el turismo de trasplantes. 